\title{
IDEOLOGY, NATIONALISM AND LAW: LEGAL TOOLS FOR AN IDEOLOGICAL MACHINERY IN LATVIA
}

\author{
DACE $\check{S} U L M A N E^{*}$
}

\section{INTRODUCTION}

To introduce the term 'ideology' to lawyers is challenging. First of all, because practicing lawyers see themselves as quite distinct from politicians, and often have a vision of ideologically neutral legal ideals, such as 'general principles of law' and 'democratic state' as cornerstones of justice.

While the term 'ideology', due to its historical Soviet context, retains negative connotations in Latvia, the absence of the word in political discourse does not mean that decisions concerning policy planning or legislation are taken with disregard for any links to ideological bases. Even more, integration within the European Union and the implementation of social and political programs and concepts are continually and imperceptibly raising questions about contemporary leading ideology (ies) and its (their) role in the development of the legal system of Latvia.

One can agree with British sociologist Alan Hunt that 'in the major texts on the sociology of law, both the old and new, the concept "ideology" is noticeable by its absence. While no single concept provides a magic key to the mysteries of law, the idea of ideology is important in understanding legal life."

For example, the historical reforms of Turkey during the 1920s and 1930s were realised as a social engineering project to Westernize/modernise the Republic, where most attention was paid to the role of legal ideology: 'the consolidation of the new order and the development of a statist understanding of justice'. ${ }^{2}$ The extensive role of law in ideological reforms was widely studied also in the Soviet Union, with research on the effectiveness of law

DOI: $10.1515 /$ wrlae-2015-0023

*Dr. iur., University of Latvia, Centre for European and Transition Studies, dace.sulmane@1v.lv

${ }^{1}$ A. Hunt, 'The Ideology of Law: Advances and Problems in Recent Applications of the Concept of Ideology to the Analysis of Law' (1985) 19 (1) Law \& Society Review 12.

2 A.Özman, 'Law, Ideology and Modernization in Turkey: Kemalist Legal Reforms in Perspective' (2010) 19 Social \& Legal Studies 3. 
and the importance of informing about legal regulations. ${ }^{3}$ It must be admitted that 'information' about the law was mostly supported by argumentation through the prism of Marxist ideology and did not involve opposing opinions. Interesting is the fact that similar conclusions were also made by Western scholars in the 1970s: 'A fundamental rule of the grammar of all modern ideology, tacit of explicitly affirmed, was the principle of the unity of theory and practice mediated by rational discourse'.

The issue of ideologies becomes more complicated and unclear when regarding specific legal reforms or Parliament's amendments to laws. It is obvious that ideas of different ideologies are manifested in the Latvian legal corpus. This article mostly focuses on elements of nationalism, trying to identify how the contemporary legislator (the Saeima) deals with the challenges of competing ideologies in the context of what remains post-Soviet legal thinking.

Regarding the conditional denial of the existence and force of ideologies on contemporary politics in Latvia, the following questions remain to be answered: is it possible to perceive the law as an instrument of ideology? Is it possible for a statenot to have a clearly defined state ideology? Is the ideological background of law a 'good or bad' phenomenon? Does society pay attention to the possible ideological idea behind the 'neutral text' of the law?

This article is less focused on providing a historical perspective on the study of ideology and more centered around a socio-legal perspective on contemporary legislation in Latvia that animates the results of debates about ideology.

This paper is structured as follows. Section II discusses the understanding of the notion 'ideology' in contemporary European political and legal science. Section III is about the perception and presence of the notion of 'ideology' in Latvian society and politics, particularly accenting the importance of the legal culture and legal consciousness of a given society. This is done in respect of the ideological force coming from the EU in the form of legislation. Section IV inquires about the actual ideological direction of laws defining the self - identity of Latvians. Section V contains conclusions.

\section{LAW AND IDEOLOGY: PRELIMINARY REMARKS}

It has been pointed out that the term 'ideology' was first used in 1797 by the French philosopher Destutt De Tracy, who developed and named a new science - the science of ideas, which 'does not hint of anything doubtful or unknown...' and provides the intellectual grounding of a new society. ${ }^{5}$ It should be noted that the notion of ideology is rarely analysed without a concrete designation: communist, nationalist, liberal etc. ideology.

\footnotetext{
${ }^{3}$ For example Кудрявцев В. Н. Никитинский В. И, Самощенко И. С., Глазырин В. В. Эффективность правовых норм [Effectiveness of Legal Norms] (Москва: Юридическая литература 1980).

${ }^{4}$ A. W. Gouldner, The dialectic of ideology and technology (The Macmillan Press 1976) 30.

5 ibid 11; D. Conversi, 'Ideology and nationalism' in K.Cordell and S. Wolff (eds) Routledge Handbook of Ethnic Conflict (Routledge 2011).
} 
The British political scientist Jonathan Leader Maynard has rightly focused on the problem that 'research (on ideology - aut.) has (..) become fragmented, rather than productively integrated.' 6 Analysing the legislative process from an ideological point of view in contemporary conditions is challenging for at least two reasons. Firstly, if there is no strong consensus from the political point of view (weak ideological self-identity of political parties, no qualitative research in political science), the term 'ideology' remains as a merely theoretical term at universities, therefore questioning the context and continuacy of practical legislation as a subject of comprehensive research. Secondly, the legislative process is not coordinated from the broader point of view (a common problem in all European countries: 'floods of norms' or 'overregulation'), thereby leading to controversies and ineffectiveness of laws as their final versions are difficult to harmonise with existing political programs (policy planning documents); they sometimes create a conceptual conflict with the existing corpus of legislation.

In the case of Latvia, a country which re-gained its independence in 1990 and took a large step from a totalitarian regime to a democratic system, the search for the substance and content of the 'democratic state' has not been easy. Unlike 'older democracies', Latvia has no long parliamentary traditions in its history, which leads to openness to various concepts and attempts at copying the good examples of other democratic states.

The problem is that in this way different, competing ideologies have found their way into legal texts and political discourse during the years that have passed since the collapse of the USSR. This has caused not only confusion among social science researchers, but also among lawyers, judges and the legislator itself. Those scholars who engage ideological issues in the social sciences are in a minority. An even smaller minority takes a further step: one towards a critique of ideology. Applying it to law may lead to results which would rarely be pleasing for the legislator. This is because, as Humphrey points out:

'Ideology critique must be able (..) to take us beyond common sense, and there is nothing unusual in seeking deeper explanations of social phenomena than those provided by first appearances. ${ }^{7}$

The possibility of such analysis has been researched by the French poststructuralist Louis Althosser, who proposed the thesis that ideology is nothing surreal or imaginary, but is instead real and observable in peoples' actions. ${ }^{8}$ Several decades later this theory was challenged by the inclusion of the attitude of society, which in certain situations can form a new type of ideology itself (as, for example, Slovenian philosopher Slavoj Žižek proposes: cynicism as a form of ideology):

'Cynical reason is no longer naïve, but is a paradox of an enlightened false consciousness: one knows the falsehood very well, one is well

\footnotetext{
${ }^{6}$ J. L. Maynard, 'A map of the field of ideological analysis' (2013) 18 (3) Journal of Political Ideologies 299.

${ }^{7}$ M. Humphrey,'(De)contesting ideology: The struggle over the meaning of the struggle over meaning' (2005) 8 (2) Critical Review of International Social and Political Philosophy.

${ }^{8} \mathrm{~L}$. Althusser, Idéologie et appareils idéologiques d'État (Notes pour une recherche) (La Pensée 1970) 38- 45 $<$ http://classiques.uqac.ca/contemporains/althusser_louis/ideologie_et_AIE/ideologie_et_A IE.pdf $>$
} 
aware of a particular interest hidden behind an ideological universality, but still one does not renounce it'.

The cynical attitude is even present in contemporary Latvian philosophy, pointing out that

'detection of ideologies, as well as preaching them, resembles walking on a narrow footbridge, where all attempts to hold the balance may be in vain'. ${ }^{10}$

There are other suggestions for trying to label contemporary developments in the 'science of ideas' in liberal democratic countries. For example, as Spanish political scientist Daniele Coversi has argued, 'modernism' refers to a wider ideological category, the belief in unlimited progress. This remained the dominant ideological paradigm at least through the beginning of the $21 \mathrm{st}$ century, and it probably still is the most popular and widespread 'ideology' across the world. ${ }^{11}$ This stream of 'modernism' is clearly seen in the legislative process of most of European countries: more detailed legal texts, more precision, more terminology, more requirements for compliance. Therefore, regarding the legal field, 'ideologies' somehow dissolve and their various elements become instrumental in service of short-term political and economic goals, not general belief systems to which the world of politics has to adapt. ${ }^{12}$

According to a recent article by Maynard ${ }^{13}$, there are several research approaches to ideology: firstly, conceptual approaches see ideologies as 'systems of ideas', and their analysis as either an intrinsically valuable investigation of political thinking or as an explanatory method for understanding political behavior. ${ }^{14}$ Secondly, for discursive approaches to ideologies the principal objects of study are the communicative practices through which ideology is constituted, transmitted and made visible. ${ }^{15}$

Maynard, when describing 'Main Agents of Ideological Change', has discussed law as one of the change agents for precisely none of the ideological approaches. This once more emphasizes that the study of the presence of ideology in law as an outcome of political process has gone widely unrecognized.

Some scholars, for example the British sociologist Alan Hunt, have acknowledged that ideology could be researched in close interconnection with legal regulation. Focusing on discussing the advantages of critical legal studies instead of classical sociology of law or normative analysis, he

\footnotetext{
${ }^{9}$ S. Žižek, The Sublime Object of Ideology (Verso 1989) 28.

${ }^{10}$ E. Freiberga, Pauls Jurevičs un nacionālā ideologija [Pauls Jurevičs and National Ideology] <http://www.fsi.lu.lv/userfiles/Kult_id_dim_\%20Freiberga.pdf $>$ accessed 20.01.2016.

${ }^{11}$ D. Conversi, 'Modernism and nationalism' (2012) 17 (1) Journal of Political Ideologies 19.

${ }^{12}$ See also M. Freeden, 'Confronting the chimera of a 'post-ideological' age' (2005) 8 (2) Critical Review of International Social and Political Philosophy 258.

${ }^{13}$ See Maynard (n 6) 314.

${ }^{14}$ Authors representing Conceptual approach : Michael Freeden, Reinhart Koselleck, Quentin Skinner.

${ }^{15}$ Two particular traditions dominate the contemporary discourse analysis of ideology: 'Critical Discourse Analysis' ('CDA') and 'the post-structuralist tradition' (PST). Authors representing discursive approach CDA: Norman Fairclough, Theo van Leeuwen, RuthWodak and Teun van Dijk. PST: Ernesto Laclau, Chantal Mouffe, Yannis Stavrakakis, David Howarth, Aletta Norval and Slavoj Žižek.
} 
distinguishes thrree different levels in analysis of the ideological character of law:

(1) the ideological content of concrete legal norms;

(2) the ideological content of principles;

(3) the ideological content of the 'form of law'. ${ }^{16}$

Analysis employing Hunt's perspective can offer new paradigms for understanding legal discourse and jurisprudence.

\section{A Constant Shadow OVER The Notion OF 'IDEOLOGY'}

The time has come to put the analysis of ideology back into work ${ }^{17}$

Although the more than 25 years which have passed since 1989 might seem a long period for the state to adopt new policies and to develop and realise substantial transformations, society may find it rather difficult to accept fundamental changes. The notion of 'ideology' has a special historical context in Latvia and probably in all post-Soviet countries. As the prominent Latvian philosopher Maija Kūle points out:

'Marxists gave the term 'ideology' a bad name, and somewhere subconsciously this feeling still remains.' 18

One can agree with $\mathrm{M}$. Freeden that

'(as) our theories of ideology were largely modelled on our experiences of totalitarianism, it is unsurprising that the passing of totalitarianism was equated with the passing of ideology'. ${ }^{19}$

Professors of political science from the University of Latvia ${ }^{20}$ basically view ideology according to Paul Ricoeur's explanation of ideology through the lens of common symbols, signs and ideas. In this case one can argue that in Latvia there are various common symbols (Song and Dance festival, Latvian national Library, Folksongs, celebration of Independence Day and Lāčplēsis Day, etc.), but there are no common ideas clearly communicated as a state ideology. As Osipova puts it:

'Historically Latvian people do not have a tradition of trusting state power and a feeling of belonging to the state. One has to work with the consciousness of people. We have had 20 years to work on it, but we did not use this time. It was only the Soviet Union which purposefully constructed state consciousness. We have not juxtaposed a common ideology and values, this is why Soviet views expressed on

\footnotetext{
${ }^{16}$ Hunt (n 1) 22.

${ }^{17}$ G. Talshir, 'The intellectual as a political actor? Four models of theory/praxis' (2005) 8 (2) Critical Review of International Social and Political Philosophy 223.

${ }^{18}$ M. Antonevičs, Ideologíja kā ideju kopums. Saruna ar Maiju Kūli [Ideology as a Totality of Ideas], 10. maijs, $2012<$ http://www.la.lv/ideologija-ka-ideju-kopums\%E2\%80\%A9saruna-ar-maiju-kuli/> accessed: 20.01.2016.

${ }^{19}$ Freeden (n 12) 250 .

${ }^{20}$ University of Latvia Faculty of Social Sciences is concentrating well-known academia in Latvian political science. Author of the article in 2014 interviewed two professors regarding the contents of the study course «Political Ideologies».
} 
the bourgeois, who rob people, speculators, onhangers and exploiters still unconciously hang in the air, 21

A similar opinion is widely shared in society, as Žižek rightly puts it, 'the passage into democracy-capitalism was experienced as deliverance from the constraints of ideology'. ${ }^{22}$ The phenomena of neutralization of the state and its values, according to Carl Schmitt, 'is a common phenomenon in liberal democracy', which 'also involves mechanization and neutralization of law'. ${ }^{23}$ The Polish scholar Mateusz Stepien argues that 'as a result of such neutrality, political decision makers can put any contents into the frames of law'. ${ }^{24}$ Legislation nowadays is influenced by different opposing ideas, targets, and ideologies to no lesser an extent than in any other historical period.

During the 1990s, in many Eastern European countries the use of such terms as Rule of Law, Democracy, Freedom or Equality, although widely used also during the Communist era, dramatically altered their substance and meaning. There was an urgent necessity to develop a new understanding of the old terminology. ${ }^{25}$ Žižek would describe these notions as 'floating signifiers', which in the given ideological field are arrenged in the necessary order around certain 'nodal points'. ${ }^{26}$

Generally, changing legal acts is much easier than changing the legal consciousness of a society. Differences between legal culture in post-Soviet and Western countries have clearly shown the long-term impact of the perception of law and civil obedience, as well as the meaning of 'rule of law'. 27

The aspect of 'ideological education' has been particularly articulated in Latvia since the referendum on the state language on 18 February $2012 .^{28}$ As a result, in the summer of 2014 the Saeima (Latvian parliament) adopted amendments to the Constitution of the Republic of Latvia with a preamble

${ }^{21}$ S. Osipova, Latvijas tautas tiesiskā apzina un Latvijas valsts [Legal Conscioussness of Latvian Nation and Latvian State] Jurista Vārds, 25.12.2012. Nr 52 (751).

${ }^{22}$ S. Žižek, 'The Spectre of Ideology. Introduction' in S. Žižek (ed) Mapping Ideology (Verso 1994)19.

${ }^{23}$ M. Stępień, 'Neutralization of Values in law in the Face of Political Value Dynamics. A Case of Using Law as Placebo' in K.Pałecki (ed), Neutralization of Values in Law (Wolters Kluwer 2013) 84.

24 ibid.

${ }^{25}$ Of course, often the previously-used terms had to be changed. For example, Latvian legal scholar Jānis Lazdinšs has analyzed the change of terminology in labor law, instead of « working discipline » implementing new term « working rules », instead of " worker, servant » introducing « employee » etc. See J. Lazdiňš, Padomju darba tiesību transformācija neatkarīgajā Latvijā [Transformation of Soviet Labour Law in Independent Latvia] (Latvijas Universitātes Raksti, Juridiskā zinātne 2004) 66. sēj., 64.lpp.

${ }^{26}$ S. Žižek, The sublime object of ideology (Verso 2008) 140 - 150.

${ }^{27}$ See M. Kurkchiyan, 'Perceptions of Law and Social Order: A Cross-National Comparison of Collective Legal Consciousness' (2001) 29 Wisconsin International Law Journal 366-392 $<$ http://hosted.law.wisc.edu/wordpress/wilj/files/2013/01/Kurkchiyan.pdf $>\quad$ accessed 20.01.2016.

${ }^{28}$ Referenduma galīgie rezultāti: pret krievu valodu kā otru valsts valodu nobalsojuši 74,8\% vēlētāju. [Final Results of Referendum: 74,8\% Voted Against Russian as Second State language].

Against Russian language as second state language: 821722 or 74,8\% voters, for - 273347 or $24,88 \%$. Diena.lv. 19.02.2012 < http://www.diena.lv/latvija/zinas/referenduma-galigierezultati-pret-krievu-valodu-ka-otru-valsts-valodu-nobalsojusi-74-8-proc-veletaj-

13932264> accessed: 20.01.2016. 
based on a proposal submitted by Egils Levits, judge of the European Court of Justice (ECJ). It emphasises the important role of the Latvian language in consolidating society. It also asserts the responsibility of individuals for their actions and bonds with society, the state and future generations. ${ }^{29}$ Latvian constitutional lawyer Ringolds Balodis pointed out that it was clear the idea to amend the introduction of the Satversme (Constitution) was in a way a response to the language referendum. ${ }^{30}$ Balodis also added that 'at a time when the Latvian State is threatened by globalisation evoked by the economic crisis, an expanded preamble would constitutionally "strengthen" the Latvian Republic's fundamental values and serve as a state ideology educational tool'. ${ }^{31}$

Therefore, one can clearly identify which accents the contemporary legislator sees as the core of state ideology: 'continuity of state' (regarding occupation regimes), 'Latvian language', 'socially responsible and national state', 'human rights', 'Latvian folk wisdom', 'Christian values'. ${ }^{32}$ Most of these values can be attributed to nationalist ideals about safeguarding the nation within its own territory. The most tricky formulations of hidden ideology in legal terms here are related to "each individual takes care of oneself', which in some cases might lead to unintended consequences regarding social security and undermine the principle of legitimate expectations. As when describing neo-liberalism, the Anglo-American anthropologist and geographer David Harvey wrote 'each individual is held responsible and accountable for his or her own actions and well-being' ${ }^{33}$ In 2014, respondents more often (46\%) indicated that the well-being of individuals is their own responsibility. In 2011, such an opinion was held only by $37 \%{ }^{34}$

In the future, the preamble to the Constitution therefore might become the most symbolic piece of legislation in recent decades in Latvia. Nevertheless, one should be aware that society ought to be more concerned

\footnotetext{
${ }^{29}$ Saeima expands the Constitution with a preamble (20.06.2014)

$<\quad$ http://www.saeima.lv/lv/aktualitates/saeimas-zinas/22361-saeima-expands-theconstitution-with-a-preamble>

${ }^{30}$ R. Balodis, 'Par likumprojektu “Grozījums Latvijas Republikas Satversmē’ Jurista Vārds, 18.03.2014. Nr 11 (813) 9-11.

31 ibid.

${ }^{32}$ The Constitution of the Republic of Latvia. Preamble. 19 June 2014 [shall come into force from 22 July 2014].

"Latvia as democratic, socially responsible and national state is based on the rule of law and on respect for human dignity and freedom; it recognises and protects fundamental human rights and respects ethnic minorities"; "Since ancient times, the identity of Latvia in the European cultural space has been shaped by Latvian and Liv traditions, Latvian folk wisdom, the Latvian language, universal human and Christian values. Loyalty to Latvia, the Latvian language as the only official language, freedom, equality, solidarity, justice, honesty, work ethic and family are the foundations of a cohesive society. Each individual takes care of oneself, one's relatives and the common good of society by acting responsibly toward other people, future generations, the environment and nature" < http://likumi.lv/doc.php?id=57980> accessed 20.01.2016.

${ }^{33}$ D. Harvey, A Brief History of Neoliberalism (Oxford University Press 2005) 65.

${ }^{34}$ Pētījums: Cilvēki vairāk paļaujas uz sevi, ne ārējiem apstākḷiem. Ir.lv. 30.aprīlis 2014 $<$ http://www.ir.lv/2014/4/30/petijums-cilveki-vairak-palaujas-uz-sevi-ne-arejiemapstakliem> accessed 20.01.2016.
} 
with "what is not written in the preamble" ${ }^{35}$ due to the fact that 'what is situated beyond the ideological can never be retrieved as a rational paradigm, and for this very reason (because it relates to a non-discursive core) it is ideology at its purest. ${ }^{36}$

The active work on the preamble of the Constitution can be also seen as a sort of nostalgia for strong ideological support for certain values, which, according to the authors of the preamble, would strengthen Latvia in the future.

\section{Post-Soviet legal consciousness challenged...}

... whatever one says is drowned in the general indifference ${ }^{37}$

For practicing lawyers and legislators the notion of legal consciousness is often unfamiliar or of secondary importance. During the 1990s one could observe a general haste to adopt new legislation, leaving the actual awareness of its implementation to the courts or to citizens themselves. This has been clearly underlined by one of the most authoritative lawyers in Latvia, ECJ judge Egils Levits, in his recent interview titled 'Overcoming the Past':

"Like a man who, accidentally losing memory, cannot adequately navigate and purposefully act, society, which has lost its collective memory, is unable to take targeted actions to develop"38

The Latvian experience shows that one generation is not enough to change society 'from within'. It is impossible and would be naïve to discuss in the abstract about deformed legal consciousness in Latvia as just a consequence of shock following drastic changes in the political regime. It seems that the real reason for the lack of trust in the legislator and in the state in general lies exactly in the first decade of regained independence (1990s). That is the period when politicians

"made their own networks of "friends and acquaintances", and they were ahead of others in terms of information - it was very "helpful" especially in the 1990s during pri(kh)vatisation. ${ }^{39}$ And that is why a large part of the society developed a sense of bitterness and distrust towards the elite of the new system: people saw that a very small number of communists were doing well, then as now, while most people were socially disadvantaged under both the occupiers and the now free Latvia."

The market economy, which, as the opposite of the Soviet-era planned economy, was introduced in Latvia in early 1990s, brought with it a large amount of new and promising concepts, previously unknown to ordinary

\footnotetext{
${ }^{35}$ It is possible to refer to Althusser's notion of a «symptomatic reading».

${ }^{36}$ F.Vighi, H. Feldner, 'Ideology Critique or Discourse Analysis? Žižek against Foucault' (2007) 6 European Journal of Political Theory 148.

37 Žižek, 'The Spectre' (n 22) 18.

${ }^{38}$ R. Kalpiña, Pagātnes pārvarēšana [Reconsidering the Past]. Interview with Egils Levits. 21. marts $2014<$ http://www.ir.lv/2014/3/21/pagatnes-parvaresana > accessed 20.01.2016.

39 The designation "pri(h)vatizācija" comes from a cynic nomination of the Russian word : «прихватить», in English «grab».

${ }^{40}$ Kalpiña (n 38).
} 
citizens. David Harvey's description can be easily attributed to Latvia since the 1990s, where politicians

"took political ideals of human dignity and individual freedom as fundamental, as "the central values of civilisation". In so doing they chose wisely, for these are indeed compelling and seductive ideals." ${ }^{41}$

Taking into account that the legal system in Latvia during the $20^{\text {th }}$ century changed six times ${ }^{42}$, each time bringing with it a change of currency, the general attitude towards trust in the state system regarding social security is low. In this way it is logical that people in Latvia hardly share the collective concerns of society, and believe and trust only their present-day individual situation.

Osipova, describing the average level of legal consciousness, pointed out that it is

"directed to obeying the law, not taking needless risks and living according to traditional values. It is described by traditionalism and conservatism. Nowadays obedience towards the law is substantially influenced by disbelief in the "sustainability" of the court system and legal norms." $" 43$

It might seem that the 'conservatism' mentioned by Osipova is also applicable to the general wish for the government to take issues into its hands and solve the problems of society. This is clearly demonstrated in a recent questionnaire which showed that $67 \%$ of Riga's residents think that social integration processes should be directed and coordinated by the state. ${ }^{44}$

The involvment of individuals in constant idological control mechanisms (school, working collective, obligatory activities outside work, 'communal' apartments, etc.), ensured access to the flow of information through their whole life. In contrast to the present time, when 'freedom', 'responisiblity' and 'rights' have allowed for the development of a new generation whose attachment to and joint responsibility for the future of Latvia as a national state is secondary. The recent decision of the Supreme Court of Latvia prohibiting the registration of a communist NGO illustrates the factual conditions: 'successful dissemination of ideology in any case can diminish the value of democracy in society'. ${ }^{45}$

\footnotetext{
${ }^{41}$ Harvey (n 33) 5.

42 S. Osipova,'Latviešu juridiskā kultūra un tiesiskā apziṇa' [Legal Culture and Legal Consciousness of Latvians] in J. Stradinšs (ed), Latvieši un Latvija. III.sējums. Atjaunota Latvijas valsts. Akadēmiskie raksti 4 sējumos (Latvijas Zinātṇu akadēmija 2013) 177

${ }^{43}$ ibid 178

${ }^{44}$ Sabiedrības integrācija Rīgā Rīgas pilsētas iedzīvotāju telefonaptauja. Analītiska atskaite. $\begin{array}{llll}\text { Jūnijs } & - & \text { augusts } & \text { TNS }\end{array}$ $<$ http://www.iksd.riga.lv/upload_file/IKSD_pievienotie/rd_iedz_aptauja_2010_isais_var.pd $\mathrm{f}>$ accessed 20.01.2016.

45 LR AT Senāta 2013. gada 30.aprīḷa spriedums lietā Nr. A42945009. [Decision of the Senate of Supreme Court. Case Nr. A42945009].
} 


\section{2. 'Legal Vaccination' to create an open European society in Latvia} ...stepping out of (...) ideology is the very form of our enslavement to it ${ }^{46}$

It is self-evident that in order to successfully implement EU legislation in a country, there has to be an adequate legal culture and environment which corresponds to the respective European values, morals and respect for the rule of law. Legal norms cannot be the only cards in the game of ideology. As Alan Hunt concluded already in 1985:

'The significance of legal ideology lies in its articulation along with other non-legal ideological bases of legitimation. ${ }^{, 47}$

This is exactly the case regarding the great efforts towards building a new society in Latvia which would be welcoming to various European Union ideas about preferable future developments. I would call this process a 'legal vaccination', which would include all kinds of legal, semi-legal and political programme activism from pro-European elements to implement vast and comprehensive changes in society at large.

Such changes are most vividly illustrated by:

a) adopting laws with strong symbolic force, so called 'symbolic laws';

b) strengthening the concepts of non-discrimination and integration in legal norms,

c) implementing policy-planning programmes with clear state (or European) budget resources to support concrete political or societychanging initiatives.

The majority of symbolic laws ${ }^{48}$ in essence are legally-formulated political programs, visions, plans, and requirements from interest groups. It facilitates the belief that the law protects these visions and plans, and that the idea of a state subject to the rule of law is being implemented in practice. ${ }^{49}$ Symbolic laws create an illusion about the binding essence of the formal legal effect of a law. It has been observed that also in Latvia symbolic laws of minimum practical importance are adopted; however, their social and political importance is immense. The symbolic effect often is characterised by changes in individuals' attitudes.

Nowadays, the study of the symbolic effects of legal provisions has become ever more important in democratic countries, thereby raising the issue of the role of 'ideological education' not merely in authoritarian regimes, but also in countries where freedom of speech and liberalism are taken as obvious.

In the past decade the European Union has expended significant effort to radically change traditional forms of identity and create a new openminded society with no barriers regarding ethnicity, race, family status, etc. This very aspect is recognized by Žižek, who argues that

'the attack on postmodern "identity politics": when class struggle in its crucial structuring function is neglected, (...) a whole series of

\footnotetext{
46 Žižek, 'The Spectre' (n 22) 6.

${ }^{47}$ Hunt (n 1) 12.

48 Czech legal scholar Jiří Přibáň has researched the «duality of the instrumental and symbolic rationality of law » in his book Legal Symbolism: On Law, Time And European Identity (Ashgate 2007).

${ }^{49}$ D. Sulmane, 'Versatility of Effects of Legal Provisions' in The Quality of Legal Acts and its Importance in Contemporary Legal Space. International Scientific Conference. 4-5 October, 2012440.
} 
different markers of social difference (gender, race, etc.) is suddenly allowed an inordinate weight'. 50

It is true that the strong accent on the 'right behaviour' has also formed the language used in society, for example, in policy planning documents, official translations of EU legal materials etc. excluding previously normal and widely-accepted notions such as 'čigāns' (gypsies) ${ }^{51}$ and using instead 'Roma'. The purposeful replacement of certain terms in law or EU policy documents with others is one of the means by which society is influenced. 'Latvian legal culture, as a legal language, nowadays ordinary, is subject to acculturization. ${ }^{52}$

Regarding sexual identity, particular attention in Latvian society was paid to a new childrens' book 'Diena, kad Kärlis bija Karlina' ('The Day when Karlis was Karlina'), which was funded by the Nordic Council of Ministers and made available for kindergartens in 2012. Nevertheless, it seems that conservative Latvian society is not ready to adopt the ideas of liberalism and feminist ideology with respect to gender identity. This is illustrated by the fact that in 2013 one of the intellectual web portals held a discussion titled 'Why is it a shame in Latvia to be a feminist?" ${ }^{53}$ The psychologist Aivis Dombrovskis concluded in his thesis that 'the cultural environment of Latvia, particularly in terms of families, is more in line with the specifics of the cultural environment in Eastern Europe and Russia, as opposed to the cultural environment and traditions of the United States or Western Europe. ${ }^{54}$ As opposed to Poland, where similar tendencies are nurtured by the conservative Catholic Church, Latvian society is still relatively widely influenced by orthodox dogmas developed in the Soviet period, and maintained by the middle-aged and older generations of society.

\footnotetext{
${ }^{50}$ Vighi, Feldner (n 36) 154.

${ }^{51}$ For example, in a recent study material for schools, one can find the term "čigāns". See „Latvijas mazākumtautības 20. gadsimtā” [History of National minorities in 20.century]. Latvijas Okupācijas $\quad$ muzejs. $\quad$ Rīga- 2014 < http://omip.lv/files/Mazakumtaut20gs\%20ok.pdf>. Nationality « čigāns » can be found in the latest statistics of the population of Latvia made by Central Statistical Bureau. Latvijas iedzīvotāju etniskais sastāvs

$<$ http://www.csb.gov.lv/sites/default/files/skoleniem/iedzivotaji/etniskais_sastavs.pdf>

52 Osipova (n 42) 178.

53 "Satori" diskusija: Kāpēc Latvijā ir kauns būt feministam? 2013. gada 14.novembrī $<$ http://www.satori.lv/raksts/6448/Kapec_Latvija_ir_kauns_but_feministam\%3F>

${ }^{54}$ A. Dombrovskis, Factors that predict the feministic identity dimensionof Latvian females. Summary of the thesis for obtaining the Doctoral Degree In Psychology (Daugavpils 2014) 93

$<$ https://du.lv/files/000/010/032/dombrovskis_kopsavilkums_precizets_saved.pdf?1406208 $325>$ accessed 20.01.2016.
} 


\section{LEGISLATION: STRENGHTHENING IDENTITY?}

\section{The state nation has the greatest responsibility for the creation of a state, and it cannot feel and act as a minority ${ }^{55}$}

Latvia since the 1990s has paid special attention to its laws regarding preservation of the status of a nation-state. Some of the core ideas of a nationstate are found directly in the law: these include laws regulating the usage of the official language, education, and citizenship. Western scholars put it simply: 'If nationalism is defined as an ideology, it can be easily described as the most powerful ideology of the modern age. ${ }^{56}$ What about Latvia in the modern age?

One of the most influential (if not the only such one) research projects in the social sciences is called 'National Identity', 57 which includes involvement of various experts in social and human sciences (political science, history, communication etc.) discussing and analysing the development of national identity. No legal scholars were involved in this project.

Nevertheless, one can agree with cultural experts Deniss Hanovs and Valdis Tēraudkalns that

'(a)mong the many problems of redesigning Latvian society, the question of how to deal with ethnic minorities has been one of the most relevant. 20 years later it can even be said that this issue is the one with the least efficient solutions applied to it. ${ }^{, 58}$

It seems that nationalism, at least in the legal sphere, has survived mostly as a cultural phenomenon. For example, there is a special law on the traditional Song and Dance Celebration ${ }^{59}$, which states:

'Section 3. The Song and Dance Celebration as a National Value

(1) The Song and Dance Celebration is a unique tradition of Latvian culture and an integral part of Latvian national identity.'

However, as judge of ECJ Egils Levits has stressed, after the restoration of independence, leading political parties and most of our political and intellectual elite, yielding to a post-colonial inferiority complex and cultivating a misunderstood form of political correctness, have increasingly avoided talking about it (national identity) or emphasizing it. Such a "cowardlatvian" ${ }^{60}$ position made the Latvian states' axiomatic base pale and

\footnotetext{
${ }^{55}$ I. Ziemele, 'Valstsnācija nevar uzvesties kā mazākumtautība' [The state nation cannot act as a minority]. Jurista Vārds, 2012.gada 3.janvāris. Ineta Ziemele is Latvian and until 2014 was a judge of ECtHR. Since 2014 - Judge of the Constitutional Court of Latvia.

${ }^{56}$ Conversi (n 11) 28.

57 National Research Programme "NATIONAL IDENTITY (language, Latvian history, culture and human security). One of the projects is called « Language - the basis of national identity $»<$ http://www.nacionala-identitate.lv/section/show/7 $>$ accessed 20.01.2016.

58 D. Hanov, V. Teraudkalns, 'Denying The Other In The Cyber Space: Democracy And Political Culture In Latvia. Analysis Of The Internet Campaign "For Mother Tongue" (November 2011)' (2012) 6 Ethnicity Ethnic Identities and Civil Society 5.

59 Dziesmu un deju svētku likums (Song and dance festival law), Latvijas Vēstnesis 99 (3257), 28.06.2005, Ziņotājs 14, 28.07.2005. Article 3. Song and Dance Festival as a national value: (1) Song and Dance Festival is a unique Latvian cultural tradition and part of Latvian national identity.

${ }^{60}$ In Latvian: gḷēvlatviska - a word created by E.Levits.
} 
blurred. As a result, Latvian national identity, the national dimension, has now become quite plain compared to other European nations. ${ }^{, 61}$

\section{Law as a means to strenghthen affiliation to Latvia}

Since 2000, the legislature has underlined several aims in the State Language Act of interest from the perspective of this article:

'Article 1 The purpose of this Act shall be to ensure:

[...]

3) the right to use the Latvian language freely in any sphere of life in the whole territory of Latvia; [...]

5) the increase of the influence of the Latvian language in the cultural environment of Latvia by promoting the faster integration of society., ${ }^{62}$ Despite all that, in 2005 the Constitutional Court of Latvia ${ }^{63}$ ruled that:

'in spite of the State language being established in the Satversme, because of historical circumstances the sufficient use of the Latvian language in the State is still endangered.' 64

As declared in the policy document 'State Language Policy Guidelines 20052014', Latvia is the European country with the highest percentage of national minorities (from 40 up to $50 \%$ ). ${ }^{65}$ As Hanovs and Teraudkalns point out, sociologists have identified a gap in the support for traditional ethnic nationalism and its elements, such as state symbols and Latvian language, between Latvians and non-Latvians. The issue of Latvian language and culture as the basis for integration politics has some of the most deeply different perceptions: $89 \%$ of Latvians and only $46 \%$ of Russians supported this idea. ${ }^{66}$ Although there are two insitutions which officialy promote and control implementation of the State Language Act, ${ }^{67}$ the reality is that Latvian

\footnotetext{
${ }^{61}$ E. Levits, Par nacionālo identitāti un demokrātisku atminuu politiku. [On Latvian identity and Policy of Democratic Memory] Jurista Vārds, 2012.gada 3.janvāris.

${ }^{62}$ Valsts valodas likums. Latvijas Vēstnesis 428/433 (1888/1893), 21.12.1999., Ziṇotājs 1, 13.01.2000.

${ }^{63}$ On the Compliance of Section 59 (Second Paragraph, Second Sentence in the Part on Participation in Financing of Private Educational Institutions if the Programs are Implemented in the Official language) of the Education Law with Article 91 of the Republic of Latvia Satversme (Constitution) and Article 14 of the European Convention for the Protection of Human Rights and Fundamental Freedoms (as Being Read in Conjunction with Article 2 of the First Protocol) Satversmes tiesas 2005. gada 14. septembra spriedums lietā Nr. 2005-02-0106. Sprieduma 9. punkts. Latvijas Vēstnesis, 16.09.2005., Nr. 148.

${ }^{64}$ Remarkable are the answers given by Latvians to the question: "Do you use Latvian to non-Latvians who understand Latvian". Only 49.8\% always use Latvian in everyday situations and 55.5\% - in official communication (LLI 1999). On the one hand, these figures reflect high level of linguistic tolerance among Latvians, on the other hand, they certify some features of still existing minority complex and linguistic indifference which could be harmful for future prospects of Latvian. See : Druviete I. Language Policy and Protection of the State Language in Latvia http://www6.gencat.net/llengcat/noves/hm01hivern/internacional/a_druviete3_4.htm>.

65 "Valsts valodas politikas pamatnostādnes 2005.- 2014.gadam" 5, accessed 20.01.2016.

${ }^{66}$ Hanov, Teraudkalns (n 58) 6.

${ }^{67}$ Valsts valodas centrs [State Language Center] (1992). Official site: www.vvc.gov.lv. Latviešu valdoas aǵentūra [Latvian Language Agency] Official site: http://www.valoda.lv/ (since 2009).
} 
is a minority language in daily business (shops, services etc). These fearbased 'collective associations, far from being artificial constructs or theoretical mirages, are viable inhabitants of the political world, easy to detect if you know where to look', 68

A completely different situation can be observed directly to the north in Estonia, where

'strong feelings of identity centre around the Estonian language, with pressure on the Russian-speaking minority to either adapt or remain excluded. ${ }^{69}$

The fact of having a referendum on a second state language in 2012 was a shock for many Latvians. Until 2012, the Latvian-speaking part of society and Latvian-oriented political parties did not acknowledge the effective capacity of Russian speakers to mobilise in order to take part in political processes. The slogans chosen for the referendum ${ }^{70}$ showed

'a combination of two collective images of the Latvian political elite to be spread among the recruited minority citizens: firstly, belief in the total corruption of the governing elite, and secondly, that the elite is of another ethnic origin than the virtual community, thus it is per definitionem not "ours", has no legitimacy to act in politics. Both ideas represent a combination of ethnic and civic alienation which are placed at the core of the message of the campaign, and the contemporary Latvian political elite is portrayed as responsible for this situation. ${ }^{, 71}$

The legal formulations in the Constitution and laws regulating status of the state language have clearly had no real impact on increasing the practical usage of the Latvian language in public (libraries, sports centres, shops, restaurants etc). Therefore, the laws regulating this domain remain ineffective.

\section{Legal tools to preserve a desirable society}

As Ricoeur righty puts it, '(it) is at the level of (..) meaningful, otheroriented and socially integrated action that the phenomenon of ideology receives its primary function'. ${ }^{72}$ A situation in which 'others' who are not a historical part of the group constituting society appear, is particularly suitable for ideologies, which emphasize the importance of distinctions like 'we/ they', 'then/ now', 'right/ wrong'.

A recent example of the new form of European support for multiculturalism has come through benefits for refugees. In April 2014,

\footnotetext{
${ }^{68}$ N.a., 'Preface: Taking ideology seriously' (2005) 8 (2) Critical Review of International Social and Political Philosophy 105.

${ }^{69}$ E. Blankenburg et al, 'Legal Culture in Five Central European Countries", WRR, Working Documents no. W111, The Hague, 2000 $<$ http://www.wrr.nl/fileadmin/nl/publicaties/DVD_WRR_publicaties_1972-

2004/W111_Legal_culture_in_five_european_countries.pdf $>$ accessed 20.01.2016.

${ }^{70}$ For example: Let us finally show those ruling thieves and nationalists that the Russians in Latvia are proud of their mother tongue and that we have honour. Jointly we will be victorious! <http://www.za-rodnoj-jazik.lv/list1.jpg> accessed 20.01.2016.

${ }^{71}$ Hanov, Teraudkalns (n 58)13-14.

${ }^{72}$ P. Ricoeur, 'Can there be a Scientific Concept of Ideology?' J. Bien (ed), Phenomenology and The Social Science: A Dialogue (Springer 1978) 45.
} 
Latvian media were flooded with news about a law providing for a monthly benefit of $€ 256$ for refugees, $€ 76$ for their children and $€ 50$ for language courses. The media compared these numbers with the average pension in Latvia - $€ 248$ and a child benefit of EUR $€ 11$ per month. Although the status of refugee in 2013 was given only to 14 persons, internet users received this with insult, which was clearly shown in titles of articles and their internet comments. ${ }^{73}$ The representative of ministry stated: "society should understand that paying benefits to refugees in Europe is a normal practice. (..) We should help refugees to integrate in our society, we cannot refuse to accept them'. ${ }^{74}$ Such an argumentation from the state "is indistinguishable from ideology ${ }^{6},{ }^{75}$ as directly sends signals about the desirable attitude, sentiments and behaviour of the society.

It is interesting to observe the reaction of the State to the significant changes of 2015 in Europe regarding immigrants (which directly affects the number of possible receivers of benefits in Latvia). As there is a plan to accept around 800 refugees in Latvia, the argument of adequate or sufficient benefit was easily dominated by the simple calculation (effect on the state budget) which was realized in the new amendments to the respective regulation. In December 2015 Cabinet of Ministers reduced the monthly benefit to $€ 139$. $^{76}$ This amendment allowed the nationalist party TB/LNNK to argue that this amendment is one of the "major achievements' of nationalistic party, "collating the amount of benefit to the average amount of benefits for Latvian inhabitants'. ${ }^{77}$ Reduction of benefits for refugees 'kills two birds': money is saved in the budget, and great concern for such principles as 'equality' and 'proportionality' is demonstrated. Instead of discussing on problems of low child benefits and pensions, it was chosen to cut the benefits of "the others" to make and illusion of equality.

\section{CONCLUSIONS}

The un-popularity of critics of ideology in law in Latvia is based on the fundamental lack of clear and indisputable affirmations of the presence of ideological inputs in many spheres of law which legal scholars usually would see as deficiencies. Historical context of the notion 'ideology' serves as a barrier for contemporary understanding of the notion, therefore causing

\footnotetext{
73 K. Putinceva, 'Bēgḷiem vairāk nekā pensionāriem' [For refugees more than for pensioneers] Diena. 2014. gada 24.aprīlis.

${ }^{74}$ Bēgli Latvijā no valsts saṇem vairāk nekā māmin̦as un pensionāri (In Latvia refugees receive more than mothers and pensioneers) www.kasjauns.lv, 28.aprīlis 2014 accessed 20.01.2016.

75 Žižek, 'The Spectre' (n 22) 15.

${ }^{76}$ Ministru kabineta noteikumi Nr. 792. 2015. gada 22. decembrī (prot. Nr. 68 49. §). Grozījumi Ministru kabineta 2014. gada 22. aprīla noteikumos Nr. 210 "Noteikumi par pabalstu bēglim un personai, kurai piešķirts alternatīvais statuss"

${ }_{77}$ Nacionālā apvienība panāk būtiskus uzlabojumus bēĝ̣lu uzṇemšanas plānā. (National Union Achieves Fundamental Improvements in Refugee Embarkation Plan] 05.11.2015 $<$ http://www.nacionalaapvieniba.lv/aktualitate/nacionala-apvieniba-panak-butiskus-

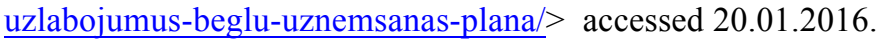


difficulties for identifying the ideological concepts in a democratic country. As a result of expressed neutrality via such notions as "rule of law", "justice", political decision makers can put any contents into the frames of law. Legislation nowadays is influenced by different opposing ideas, targets, ideologies not less than in any other historical period.

It is true that the strong accent on the 'right behaviour' has formed also language used in society, for example, in Policy planning documents, official translations of EU legal materials.

In Latvian context national ideology has not been successful in strengthening the status of Latvian language and citizenship, causing the initiatives to solve this deficiency with a new preamble to the Constitution. European values of tolerance, inclusion etc. are implemented in conservative society such as Latvian society through legislation and financing projects is an effective way to achieve formal results, but the conditions of general legal consciousness (or lack of it) are much slower to change.

\section{References}

Althusser L., Idéologie et appareils idéologiques d'État (Notes pour une recherche) (La Pensée

1970) http://classiques.uqac.ca/contemporains/althusser_louis/ideologie_et_AIE/id eologie_et_AIE.pdf $>$

Antonevičs M., Ideologija kā ideju kopums. Saruna ar Maiju Kūli [Ideology as a Totality of Ideas], 10. maijs, 2012 $<$ http://www.la.lv/ideologija-ka-ideju-kopums $\%$ E2\%80\%A9-saruna-armaiju-kuli/>

Balodis R., 'Par likumprojektu "Grozījums Latvijas Republikas Satversmē' Jurista Vārds, 18.03.2014., Nr 11 (813).

Blankenburg E. et al, 'Legal Culture in Five Central European Countries", WRR, Working Documents no. W111, The Hague, December 2000 $<\mathrm{http}: / /$ www.wrr.nl/fileadmin/nl/publicaties/DVD_WRR_publicaties_19722004/W111_Legal_culture_in_five_european_countries.pdf $>$.

Conversi D., 'Modernism and nationalism' (2012) 17 (1) Journal of Political Ideologies.

Conversi D., 'Ideology and nationalism' in K.Cordell and S. Wolff (eds) Routledge Handbook of Ethnic Conflict (Routledge 2011).

Dombrovskis A., Factors that predict the feministic identity dimensionof Latvian females. Summary of the thesis for obtaining the Doctoral Degree In Psychology (Daugavpils 2014) $<$ https://du.lv/files/000/010/032/dombrovskis_kopsavilkums precizets_save d.pdf?1406208325> .

Freeden M., 'Confronting the chimera of a 'post-ideological' age' (2005) 8 (2) Critical Review of International Social and Political Philosophy.

Freiberga E., Pauls Jurevičs un nacionālā ideologija [Pauls Jurevičs and National $<$ http://www.fsi.lu.lv/userfiles/Kult_id_dim_\%20Freiberga.pdf $>$ Ideology]

Gouldner A. W., The dialectic of ideology and technology (The Macmillan Press 1976). 
Hanov D., Teraudkalns V., 'Denying The Other In The Cyber Space: Democracy And Political Culture In Latvia. Analysis Of The Internet Campaign "For Mother Tongue" (November 2011)' (2012) 6 Ethnicity Ethnic Identities and Civil Society.

Harvey D., A Brief History of Neoliberalism (Oxford University Press 2005).

Humphrey M.,'(De)contesting ideology: The struggle over the meaning of the struggle over meaning' (2005) 8 (2) Critical Review of International Social and Political Philosophy.

Hunt A., 'The Ideology of Law: Advances and Problems in Recent Applications of the Concept of Ideology to the Analysis of Law' (1985) 19 (1) Law \& Society Review.

Kalpiņa R., Pagātnes pārvarēšana [Reconsidering the Past]. Interview with Egils Levits. 21. marts $2014<$ http://www.ir.lv/2014/3/21/pagatnesparvaresana $>$

Kurkchiyan M., 'Perceptions of Law and Social Order: A Cross-National Comparison of Collective Legal Consciousness' (2001) 29 Wisconsin International Law Journal 366-392 $<$ http://hosted.law.wisc.edu/wordpress/wilj/files/2013/01/Kurkchiyan.pdf $>$.

Lazdiņš J., Padomju darba tiesību transformācija neatkarīgajā Latvijā [Transformation of Soviet Labour Law in Independent Latvia] (Latvijas Universitātes Raksti, Juridiskā zinātne 2004).

Levits E., Par nacionālo identitāti un demokrātisku atmiṇu politiku. [On Latvian identity and Policy of Democratic Memory] Jurista Vārds, 2012.gada 3.janvāris.

Maynard J. L., 'A map of the field of ideological analysis' (2013) 18 (3) Journal of Political Ideologies.

N.a., 'Preface: Taking ideology seriously' (2005) 8 (2) Critical Review of International Social and Political Philosophy.

Osipova S.,'Latviešu juridiskā kultūra un tiesiskā apziņa' [Legal Culture and Legal Consciousness of Latvians] in J. Stradiņš (ed), Latvieši un Latvija. III.sējums. Atjaunota Latvijas valsts. Akadēmiskie raksti 4 sējumos (Latvijas Zinātņu akadēmija 2013)

Osipova S., Latvijas tautas tiesiskā apziņa un Latvijas valsts [Legal

Consciousness of Latvian Nation and Latvian State]. Jurista vārds. 25. 12. 2012, nr 52 (751).

Özman A, 'Law, Ideology and Modernization in Turkey: Kemalist Legal Reforms in Perspective' (2010) 19 Social \& Legal Studies.

Přibáň J., Legal Symbolism: On Law, Time And European Identity (Ashgate 2007).

Putinceva K., 'Bēgļiem vairāk nekā pensionāriem' [For refugees more than for pensioneers] Diena. 2014. gada 24.aprīlis.

Ricoeur P., 'Can there be a Scientific Concept of Ideology?' J. Bien (ed), Phenomenology and The Social Science: A Dialogue (Springer 1978).

Stępień M., 'Neutralization of Values in law in the Face of Political Value Dynamics. A Case of Using Law as Placebo' in K.Pałecki (ed), Neutralization of Values in Law (Wolters Kluwer 2013). 
Šulmane D., 'Versatility of Effects of Legal Provisions' in The Quality of Legal Acts and its Importance in Contemporary Legal Space. International Scientific Conference. 4-5 October, 2012.

Talshir G., 'The intellectual as a political actor? Four models of theory/praxis' (2005) 8 (2) Critical Review of International Social and Political Philosophy.

Vighi F., Feldner H., 'Ideology Critique or Discourse Analysis? Žižek against Foucault' (2007) 6 European Journal of Political Theory.

Ziemele I., 'Valstsnācija nevar uzvesties kā mazākumtautība' [The state nation cannot act as a minority] Jurista Vārds, 2012.gada 3.janvāris.

Žižek S., 'The Spectre of Ideology. Introduction' in S. Žižek (ed) Mapping Ideology (Verso 1994)19.

Žižek S., The Sublime Object of Ideology (Verso 1989).

Žižek S., The sublime object of ideology (Verso 2008).

Кудрявцев В. Н. Никитинский В. И, Самощенко И. С., Глазырин В. В. Эффективность правовых норм [Effectiveness of Legal Norms] (Москва: Юридическая литература 1980). 